\title{
Translating Characters: Eliza Doolittle "Rendered" into Spanish
}

\author{
Edurne Goñi Alsúa \\ Public University of Navarre, Spain
}

Copyright (c) 2018 by Edurne Goñi Alsúa. This text may be archived and redistributed both in electronic form and in hard copy, provided that the author and journal are properly cited and no fee is charged for access.

\begin{abstract}
Pygmalion, one of the best known of George Bernard Shaw's plays in Spain, was translated and performed in 1919 and published in 1920. Up to 2016, it has been rendered into Spanish five times. The main character in Pygmalion is Eliza, a Cockney woman who feels the need to change her life to accede to the middle class. Shaw characterized Eliza in two ways, her clothes and her speech, as she speaks the dialect of her socio-geographical background, Cockney. Translators tend to fail to do justice to Eliza's characterization for two reasons. The first is the lexical and grammatical choices, which do not always convey the same ideas as those implied in the original text. The second is the sociolinguistic disparity between the original English dialects and the Spanish dialects chosen in the translations. We should also consider that attitudes to the social place of women have evolved in the century since Pygmalion was first published. In this paper I show the different "Elizas" which are presented in the different Spanish editions of Pygmalion.
\end{abstract}

Key Words. Translation, Dialects, Geolects, Pygmalion, Cockney, Characterization.

Resumen. Una de las obras más famosas de George Bernard Shaw en el mundo hispanohablante es Pigmalión, que fue traducida, representada y publicada en nuestro país entre 1919 y 1920, llegando a convertirse en todo un éxito, de la misma manera que ya lo había sido en Inglaterra. Desde ese momento hasta la actualidad, podemos contabilizar otras cinco traducciones de la misma obra, cuatro de ellas llevadas a cabo en España y otra en Argentina. Pero estas obras meta no retratan a Eliza, la protagonista, de la misma manera de la que Shaw la caracterizó. Debemos tener en cuenta, por un lado, que la concepción sobre la mujer ha evolucionado mucho desde que se publicó por primera vez y estas diferencias fueron marcadas por Shaw en una segunda edición de la misma, llevada a cabo en 1941, lo que lleva a una primera distinción palpable. Por otro, las elecciones léxicas y gramaticales llevadas a cabo por los autores meta no siempre transmiten las mismas ideas que las que aparecen en el original. Debemos destacar, así mismo, que el autor irlandés utiliza el tagging para mostrar una de las principales características de Eliza, su inseguridad, pero esta estructura no es gramaticalmente correcta en nuestra lengua. En este artículo vamos a mostrar a las distintas 
«Elizas» con las que contamos en las seis ediciones de esta obra de teatro en nuestra lengua, exponiendo las diferencias en la traducción de los diferentes autores meta.

Palabras clave. Traducción, dialectos, geolectos, censura, Pygmalion, cockney, personalidad.

George Bernard Shaw, who is considered to be one of the most important playwrights in English - preceded only by William Shakespeare - wrote Pygmalion as a criticism of the British social establishment and a vindication of women's rights. Still, moving away from the well-known plot, I would like to focus on the language, which Gallardo has noted:

An interesting fact ... is that most people read Pygmalion considering it as a play about social class (Cameron, 1995), i.e., the language difference there is between the two main characters Henry Higgins and Eliza Doolittle is due to the fact that they belong to different social classes and different educational background [sic]. If people take this idea into consideration, they may say that their language, in this case, is simply 'a reflection of social differences'. (17)

I would like to concentrate on one of the dialects which Shaw used in this play, Cockney, and on its translation into Spanish. One of the challenges with which translators must deal is the need to render accurately two aspects of a text: on the one hand, all the subtleties of the language utilized by the author and, on the other, all the nuances of the personality of the characters. However, this last task is sometimes impossible, due to the fact that, in many instances, the words are not completely synonymous and bear different connotations. We can observe this in the five Spanish translations of Pygmalion. Goñi-Alsúa (2017) studied these renderings of Pygmalion and identified their chronological order: Julio Broutá in 1919, Ricardo Baeza in 1943, Floreal Mazía in 1952, Juan Leita in 1985, and Miguel Cisneros in 2016. These five translations cover nearly a century and two continents, three were published in Spain for a Spanish audience, one in Argentina for the Argentine audience, and another was printed in Argentina, but for a Spanish audience, as the dialects used are those of Spain. Added to these, there exists another version, as we will see, printed in Spain in 1990.

Yet, before commencing our study about how the choice of words in the target language can change the personality of a character, we must consider certain points which have influenced or defined Pygmalion and its reception in Spain. To begin with, the process of the play's composition is important in itself because Bernard Shaw, as a convinced feminist, wrote a new edition of the play with modifications and additions to emphasize this aspect, twenty-five years after the first edition. Likewise, we must also consider the processes of translation and reception in the social context of Spain, a democratic country which experienced a civil war and then was governed by a dictatorial regime which established censorship. Moreover, we should pay attention to the sociolinguistic understanding of the linguistic variation presented by the main character to fully comprehend the play. Finally, it is essential to analyse the process of the translation of theatre drama, inasmuch as this art form bears certain features which make it unique, added to which is Merino's interesting assertion that there is a human element when a play is performed in another country and language (Traducción 22).

We must begin by explaining the production process of Pygmalion, which Miguel Cisneros Perales discusses in the study preceding his translation of the play (Shaw, 2016 3338). According to Cisneros, in 1897, Shaw had in mind a play about the relationship between 
a lord from West London and a girl wearing an apron and three red-and-orange ostrich feathers, and had even decided who would play them: Johnston Forbes Robertson and Mrs Patrick Campbell. Shaw started to write the play on 7 March 1912 and finished it three months later on 10 June. Owing to the negative reviews which his previous plays had received in England, he decided to premiere Pygmalion in Vienna, on 17 October 1913. Following its success in this continental city, Shaw accepted to put on Pygmalion in London, where it premiered on 10 June 1914. That year, the play was published in two North American journals, Everybody's Magazine in November and Nash's and Pall Mall Magazine in December. British readers had to wait until 1916, when it was published in London. Nine years later, in 1925, Bernard Shaw was awarded the Nobel Prize for Literature and in 1939 the Oscar for Best Screenplay for the film version of Pygmalion, which had been directed the previous year by Anthony Asquith and Leslie Howard and starred Howard. However, since its first performance, the final scene had been modified without Bernard Shaw's consent, to introduce romance into the play and to please audiences, which led him to edit it. In 1940, he rewrote some dialogue, added some scenes, such as a new one at the end of the first act (Shaw, 1990 30), changed the end, and included an epilogue (Shaw, 1990 134); this new version was published in 1941.

From the point of view of the Spanish reception, we should also consider two historical facts which moulded the society of this country. First, the Spanish Civil War, which broke out in 1936 and ended in 1939, and then the dictatorial Franco regime which governed the country from 1939 to 1975 . According to Fernández, Spain was immersed in a deep social crisis built on three main foundations, the army, the capital, and the Catholic Church, with a leader who had assumed all the powers and banned political parties (123-138). Moreover, Spain was politically and culturally isolated, and most of its intellectuals were forced into exile. The dictatorship also imposed religious and moral rules upon the population through censorship, which altered in many cases the reception of both foreign and national literary works. It should not be forgotten that during the 1940s and 1950s, the international literary scene saw such important movements as Existentialism and Realism. Miguel even claims that state censorship sought to impose a particular interpretation of the literary works to which the public was still allowed access (61). Theatre was also carefully surveilled. As Muñoz explains, the censors maintained that theatre's subversive potential was greater than literature as it was directed to a collective audience (85) and because it supposed an escape from daily concerns to experiences which were very often unattainable (Miguel 61). Or, as Esslin notes, theatre "provides some of the principal role models by which individuals form their identities and ideals, sets patterns of communal behaviour, forms values and aspirations, and has become part of the collective life of the masses" (14). However, fortunately, the censors did not eliminate much from Pygmalion due to the fact that, by the time the tribunal was established, the play had been published to a warm reception from the public and critics and performed with great success. It is true that the red pencil crossed out some sentences, but these were not related to Eliza, rather to her father and his marital situation.

Focusing on Pygmalion, the main female character, Eliza, is a Cockney girl from East London who sells bunches of flowers in the street and dreams of working as a shop assistant in a florist's, but the issue is that she needs to change the way she speaks. In her own words, "I want to be a lady in a flower shop stead of sellin at the corner of Tottenham Court Road. But they wont take me unless I can talk more genteel" (Shaw, 1980 22-23). At this point, we should talk about geolects. Gimeno defines this concept as a geographical and social linguistic variation, as all speakers are marked by two dimensions, one geographical and the other social. In addition, Gimeno explains that geolects are linked to the speaker's situation and are, essentially, social variations of speech (163). If we analyse Cockney, we observe that it 
responds perfectly to this definition, as it is a linguistic variation spoken by a low social class of people living in an impoverished neighbourhood of London.

More important than its definition as a linguistic variation, is Cockney's sociolinguistic acceptance. Cockney speakers are widely and generally "disadvantaged by negative attitudes towards them" (Holmes 356), as this linguistic variation has always been looked down upon, not only by other inhabitants of London, but across the whole country; it is "den[ied] ... the status of a dialect and describe[d] ... as a vulgar speech based upon error and misunderstanding" (Matthews xii). I would also like to reproduce here some words which show how the English considered this geolect at the time Shaw wrote Pygmalion. A speaker at the 1909 Conference on the Teaching of English in London Elementary Schools said that "The Cockney mode of speech, with its unpleasant twang, is a modern corruption without legitimate credentials, and is unworthy of being the speech of any person in the capital of the Empire" (Matthews 157). Soto also maintains that this dialect marks the separation or segregation of a community or a character or the reaffirmation through linguistic idiosyncrasy of a different way of life (24). As Shaw himself wrote, "it is impossible for an Englishman to open his mouth without making some other Englishman despise him" (1980 xi).

Therefore, the Cockney geolect in this play is more than just a random choice. According to Tello, it has a distancing and stigmatizing function (142), because the speaker of this geolect is "ashamed of his dialect" (Matthews xiv). Thus, in a world which rejects her, one of the main features defining Eliza is her insecurity, especially when she fears that she can be harmed by the world around her, as she is conscious of the differences of social class which stand between her, a working-class girl, and the job she dreams of. Hatim and Mason confirm (103-110) that this insecurity is shown in the text by certain recurrent sentences, in which Eliza repeats that she is an honest person, and tagging, the repetition of short sentences - subject and auxiliary verb - which Shaw uses to emphasize what she says, such as, "I am a good girl, I am" (1980 11). The problem here is that this structure - tagging - is not used in Spanish, so the translators must resort to other means - generally lexical - of conveying the same idea, which can change this aspect of her personality.

Furlanetto states that a play is written to be performed and represents characters and conflicts which, seen on stage, seem to happen in real life. She also notes that a playwright must represent the features of the characters through both dialogue and action (16). Merino underlines another feature of theatre: action is more important than description and dialogues prevail over narration of the events (Traducción 18). From these concepts, we can deduce that translators must reproduce characters' speech accurately, as it is the basis of a play.

I will show, by means of some examples taken from the various translations, how grammatical and lexical choices and the way in which the translators render Eliza's dialect change her personality. This young woman is depicted as polite, resolute, strong-willed, independent, and witty, possessing dignity and self-respect, and determined to rise in life despite her lack of education. In Matlaw's words, "Eliza is only very gifted. She personifies the potential of a human being - perhaps any human being - given the proper guidance" (31); and Pacheco described her as a very real woman, like all of Shaw's female characters (2013 52).

As a means of comparison, we use the replica or utterance, defined by Merino as "the words to be delivered by a certain actor, including the name of the character, the words to be said on the stage and the stage directions related to these words" ("A Framework" 130). We have maintained the original language and spelling used by Shaw, as these two aspects were carefully chosen by the author, as he himself explains: 
[T]he apostrophes in ain't, don't, haven't, etc. look so ugly that the most careful printing cannot make a page of colloquial dialogue as handsome as a page of classical dialogue. Besides, shan't should be sha'n't, if the wretched pedantry of indicating the elision is to be carried out. I have written aint, dont, havnt, shant, shouldnt and wont for twenty years with perfect impunity, using the apostrophe only where its omission would suggest another word; for example, hell and he'll. There is not the faintest reason for persisting in the ugly and silly trick of peppering pages with these uncouth bacilli. I also write thats, whats, lets, for Ae colloquial form of that is, what is, let us; and I have not been prosecuted. (Shaw and Lerner xiii)

I italicize examples of the features explained, both in the original and in the translated texts, to show the changes more clearly.

\section{Julio Broutá (1919)}

Brouta is the translator who introduced Shaw to Spain and translated his plays until his death in the 1930s. He translated Pygmalion from the English edition of 1916 and, as he states in his version, it was intended for the stage. He submitted his translation to Gregorio Martinez Sierra, who adapted it to the Spanish stage, suppressing the first act and modifying the end of the fourth (Shaw, 1973 657).

When Pygmalion burst onto the Spanish scene, Spain was a democratic country, although it was suffering deep political and economic crisis caused by nearly a century of civil wars. In those years, the theatre was very popular and Spaniards were accustomed to specific types of play which mainly featured working-class characters, humour, and the dialect spoken by the lower classes of Madrid. Seco asserts that these characteristics, humour and popular language, merge in the work of Carlos Arniches, one of the genre's leading playwrights, in such a way that it is impossible to disregard one when we analyse the other (10). For this reason, Broutá substitutes certain aspects of the original to adapt it to the genre of play preferred by the Spanish audience which crowded the theatres, although, as Broutá explains in a footnote after the first utterance by Eliza, the critics did not consider it correct to translate Cockney into the language spoken by Madrid's lower classes (Shaw, 1968 662).

Broutá's adaptations affect Eliza in two ways. First, he shows her sociolinguistic background by means of cheli, a geolect spoken by the lower classes of Madrid, riddled with phonetic vulgarisms, words of Gypsy origin, and cultured words deformed by incorrect use of the population (Arniches 17). However, this geolect is less deeply marked than Cockney, which renders both Eliza's speech and her personality softer than in the original. In addition, Eliza feels more confident as Broutá neutralized the tagging - because, as mentioned above, this grammatical structure is not used in Spanish - and so his choice of words do not show her insecurity as strongly.

If we analyse her discourse we can observe the following:

1. Due to the fact that Broutá removed the tagging, the same idea must be expressed in other ways and the nuance of Eliza's insecurity is diluted or reversed.

1.1. Broutá inserts terms, which in this case reinforces Eliza's security due to the strong pronunciation of the last, added, word:

\begin{tabular}{|l|l|}
\hline Original & Translation \\
\hline $\begin{array}{l}\text { "THE FLOWER GIRL: I am a good girl, I } \\
\text { am" }\end{array}$ & "LA FLORISTA: soy una chica honrá" \\
\hline
\end{tabular}


1.2. He develops phrases:

\begin{tabular}{|l|l|}
\hline Original & Translation \\
\hline $\begin{array}{l}\text { "THE FLOWER GIRL. Frightening people } \\
\text { like that! How would he like it himself" }\end{array}$ & $\begin{array}{l}\text { "LA FLORISTA.- Debiera denunciarle, } \\
\text { por coación" }\end{array}$ \\
\hline
\end{tabular}

The word "coación", misspelled and stressed in the last syllable, supposes a soft threat which reinforces an image of self-confidence.

1.3. He develops complex sentences which don't appear in the original:

\begin{tabular}{|c|c|}
\hline Original & Translation \\
\hline- & $\begin{array}{l}\text { "LA FLORISTA.- Oiga usté, cabayero; } \\
\text { diga usté la verdá. ¿Qué es lo que he hecho } \\
\text { yo? Yo no he quitao naa a nadie. Que me } \\
\text { registren" }\end{array}$ \\
\hline
\end{tabular}

\begin{tabular}{|l|l|}
\hline Original & Translation \\
\hline "THE FLOWER GIRL. Ow, eez ye-ooa san, & "LA FLORISTA.-Anda, ¿conque es hijo de \\
is e? Wal, fewddan y' de-ootybawmz a & usted, señora? Bien. Pues mire: podrá usted \\
mather should, eed now bettern to spawl a & pagarme las flores estropeás. No se figure \\
pore gel's flahrzn than ran awyatbahtpyin. & usted que a mí me las regalan" \\
Will ye-oopy me f'them" & \\
\hline
\end{tabular}

2. On the other hand, the Spanish Eliza speaks, as we have mentioned, a geolect of Madrid called cheli, represented in the text by colloquial utterances which make the appearance of the dialect lighter. I have no doubt that the actors on stage imitated the phonetics and intonation patterns of cheli, suprasegmental elements which cannot be reflected in the written text.

The main features used to represent the sociolect, which present Eliza as more colloquial rather than strictly dialectal, are:

\subsection{Translated forms:}

\begin{tabular}{|l|l|}
\hline Original & Translation \\
\hline "THE FLOWER GIRL Garn" & "ELIZA Anda la mar" \\
\hline
\end{tabular}

\subsection{Added forms:}

\begin{tabular}{|l|l|}
\hline Original & Translation \\
\hline $\begin{array}{l}\text { "THE FLOWER GIRL Nah then, Freddy: } \\
\text { look wh' y' gowin, deah" }\end{array}$ & $\begin{array}{l}\text { "LA FLORISTA ;Vaya unas maneras que } \\
\text { tienen algunos! ;Moño, las tienen de ...! ; } Y \\
\text { poco barro que hay! ;Pues ya nos hemos } \\
\text { ganao el jornal!” }\end{array}$ \\
\hline
\end{tabular}

2.3. Inclusion of uneducated forms through the translation:

\begin{tabular}{|l|l|}
\hline Original & Translation \\
\hline “THE FLOWER GIRL. Don’t you be so & "LA FLORISTA.- ¡No se ponga tan bufo, \\
\hline
\end{tabular}


saucy. You ain't heard what I come for yet.

Did you tell him I come in a taxi?" hombre! Un griyo sólo vale medio penique y se l'oye. Entéres'usté tan siquiera del ojezto de mi vesita. Señora, ¿l'ha dicho usté que he venío en taxi?"

Inclusion of uneducated forms through the addition of sentences or words:

\begin{tabular}{|l|l|}
\hline Original & Translation \\
\hline "THE FLOWER GIRL. I didn't" & $\begin{array}{l}\text { "LA FLORISTA. - ¿No ha de gritar una } \\
\text { cuando la pisan un callo?" }\end{array}$ \\
\hline
\end{tabular}

\begin{tabular}{|l|l|}
\hline Original & Translation \\
\hline $\begin{array}{l}\text { "THE FLOWER GIRL. Nah then, Freddy: } \\
\text { look wh' y' gowin, deah" }\end{array}$ & $\begin{array}{l}\text { "LA FLORISTA.- ¡Anda, pasmao! ;Vaya } \\
\text { con señorito cegato! Nos ha amolao el } \\
\text { cuatro ojos. ¡Ay, qué leñe!” }\end{array}$ \\
\hline
\end{tabular}

\begin{tabular}{|l|l|}
\hline Original & Translation \\
\hline $\begin{array}{l}\text { "THE FLOWER GIRL There's menners f' } \\
\text { yer! Te-oobanches o voylets trod into the } \\
\text { mad" }\end{array}$ & $\begin{array}{l}\text { "LA FLORISTA.- ¡Vaya unas maneras que } \\
\text { tienen algunos! ;Moño, las tienen de ...! ; } Y \\
\text { poco barro que hay! ;Pues ya nos hemos } \\
\text { ganao el jornal!" }\end{array}$ \\
\hline
\end{tabular}

2.4. Broutá plays with elements which show good manners

He omits sentences:

\begin{tabular}{|l|l|}
\hline Original & Translation \\
\hline $\begin{array}{l}\text { "THE FLOWER GIRL I can give you } \\
\text { change for a tanner, kind lady" }\end{array}$ & - \\
\hline
\end{tabular}

He adds colloquial expressions:

\begin{tabular}{|l|l|}
\hline Original & Translation \\
\hline $\begin{array}{l}\text { "THE FLOWER GIRL. If it's worse it's a } \\
\text { sign it's nearly over. So cheer up, Captain; } \\
\text { and buy a flower off a poor girl" }\end{array}$ & $\begin{array}{l}\text { "LA FLORISTA.- Cuando cae así, con } \\
\text { fuerza, no crea usted cabayero, es que } \\
\text { pronto se acaba. Ande, mi general, } \\
\text { compreme un ramyete" }\end{array}$ \\
\hline
\end{tabular}

He adds expressions which show good manners:

\begin{tabular}{|c|c|}
\hline Original & Translation \\
\hline "THE FLOWER GIRL. Oh, thank you, lady" & $\begin{array}{l}\text { "LA FLORISTA.- ¡Qué buena es la señora! } \\
\text { ¡Si toas fuan así!" }\end{array}$ \\
\hline Original & Translation \\
\hline $\begin{array}{l}\text { "THE FLOWER GIRL. Thank you kindly, } \\
\text { lady" }\end{array}$ & $\begin{array}{l}\text { "LA FLORISTA.- Muchísimas gracias, } \\
\text { señora, y que tenga usted mucha saluz"" }\end{array}$ \\
\hline
\end{tabular}


We should consider these two last utterances as ways for Eliza to gain the sympathy of potential buyers.

\section{Ricardo Baeza (1943)}

Baeza translated Pygmalion in 1943 for publication in Argentina, due to the shortage of paper in Spain as a consequence of the Civil War. Goñi-Alsúa (2017) has demonstrated that this version is a variation of the text produced by Broutá, an intracultural translation in which Baeza copied most of the text, and changed or modified some parts; the basis is the Spanish edition of 1919. Because of this, comparison must be also made with Broutá's translation, not only with Shaw's original text.

In this translation, too, Eliza is not the same person as in the original: she sounds more confident as Baeza too eliminates the tagging and the repetition, and shows a new aspect of her personality: she feels the need to defend herself. Eliza also sounds ruder, due to the lexical choices made by the translator and the contractions which he includes in the speech of the characters who use dialect.

We must underline that although this version was printed in Argentina, it was intended for a Spanish audience, as we can observe, thanks to two features. The first is that the dialect which Baeza uses is spoken in the Iberian Peninsula, not in Argentina. The second is that throughout the play, the translator reflects the moral values which the dictatorial government tried to impose on Spanish society. This latter point mostly relates to Mr Doolittle, Eliza's father, so they are not reproduced here.

\section{Eliza gains self-confidence}

\subsection{Indicators of confidence:}

\begin{tabular}{|l|l|}
\hline Original & Translation \\
\hline "THE FLOWER GIRL. Ow, eez ye-ooa san, & "LA FLORISTA Anda, ¿conque es hijo de \\
is e? Wal, fewddan y' de-ootybawmz a & usté? Pues mire,ya podía pagarme las \\
mather should, eed now bettern to spawl a & flores estropeás. No se figure usté que a mí \\
pore gel's flahrzn than ran awyatbahtpyin. & me las regalan" \\
Will ye-oopy me f'them" & \\
\hline
\end{tabular}

The word "podía" is not used here as a conditional form, but as an "invitation" to oblige the mother to pay for the flowers which her son has ruined.

\subsection{Indicators of self-defence:}

\begin{tabular}{|l|l|}
\hline Original & Translation \\
\hline $\begin{array}{l}\text { "THE FLOWER GIRL It's because I called } \\
\text { him Captain. I meant no harm. Oh, sir, don't } \\
\text { let him lay a charge agen me for a word like } \\
\text { that. You-" }\end{array}$ & $\begin{array}{l}\text { yamao general al señor? ¿Y qué, es algún } \\
\text { crimen? Usté dirá, cabayero, si me he } \\
\text { propasao en algo" }\end{array}$ \\
\hline
\end{tabular}

Eliza also defends her honour more vehemently:

\begin{tabular}{|l|l|}
\hline Original & Translation \\
\hline $\begin{array}{l}\text { "THE FLOWER GIRL I'm a good girl, I } \\
\text { am" }\end{array}$ & $\begin{array}{l}\text { "LA FLORISTA ¡Yo soy una muchacha } \\
\text { honrá!" }\end{array}$ \\
\hline
\end{tabular}


As we can observe, the translator has heightened the tone in two ways: he turns a declarative sentence into an exclamation, and includes the subject of the sentence, which is not compulsory in Spanish, as the subject is shown in the verb morphemes, and is used to reinforce the person who performs the action.

\section{Eliza is ruder}

\subsection{Translated vocabulary:}

\begin{tabular}{|l|l|}
\hline Original & Translation \\
\hline $\begin{array}{l}\text { “THE JAPANESE LADY. Garn! Don't you } \\
\text { know your own daughter?” }\end{array}$ & \begin{tabular}{l} 
'LA DAMISELA mi padre!” \\
\hline
\end{tabular} \\
\hline
\end{tabular}

The Cockney word garn sounds strong because of the sociolinguistic considerations this geolect conveys but, in Spanish, it is not dialectal, simply rude.

\begin{tabular}{|l|l|}
\hline Original & Translation \\
\hline $\begin{array}{l}\text { "LIZA Oh you are a brute. It's a lie: nobody } \\
\text { ever saw the sign of liquor on me" }\end{array}$ & $\begin{array}{l}\text { "ELISA Pero ¿qué s'ha figurao usté? ¿Que } \\
\text { es lo que faltaba!"” }\end{array}$ \\
\hline
\end{tabular}

In this translation, we see the movement of the implied meaning from "I do not drink" to "I am not a drunken prostitute".

\subsection{Sentences included by the translator:}

\begin{tabular}{|l|l|}
\hline Original & Translation \\
\hline "THE FLOWER GIRL. I didn't" & $\begin{array}{l}\text { "LA FLORISTA ¿Qué, se va a cayar una } \\
\text { cuando la atropeyan? iPues 'tariamos } \\
\text { frescos!" }\end{array}$ \\
\hline
\end{tabular}

To answer back to somebody who is supposed to be superior has always been a sign of rudeness, and this is what Eliza is doing here. From a simple "no", in Spanish she refuses the idea of being silent and confronts all those who disturb her.

\begin{tabular}{|l|l|}
\hline Original & Translation \\
\hline "THE FLOWER GIRL Ah--ow--ooh! Aaah-- & "LA FLORISTA ¡Ay mi madre! ¡Ujujuy! \\
ow--ooh! Aaaaaah--ow--ooh! & ¡Habráse visto tío más chalao!” \\
Aasaaaaaaaaah--ow--ooh!!!” & \\
\hline
\end{tabular}

At this point, the Spanish Eliza dares to insult Higgins, which does not happen in the original, where her utterance is a simple exclamation.

2.3. Phonetic representations of the words:

\begin{tabular}{|l|l|}
\hline Original & Translation \\
\hline "THE FLOWER GIRL. Don't you be so & "LA FLORISTA No se ponga tan rufo, \\
saucy. You ain't heard what I come for yet. & hombre. Un griyo sólo vale medio penique \\
Did you tell him I come in a taxi?" & y se l'oye. Entéres'usté tan siquiera del \\
\hline
\end{tabular}


ojeto de mi vesita. Señora, ¿l'ha dicho usté que he venío en tasi?"

At the beginning of the play, Shaw transcribes Eliza's speech phonetically by means of the ordinary alphabet but abandoned this approach for, as he explained, "Here, with apologies, this desperate attempt to represent her dialect without a phonetic alphabet must be abandoned as unintelligible outside London" (1989 7). In contrast, the translator maintains the transcription by means of contractions and phonetic presentation of the vulgar pronunciation she uses.

Regarding this translation, we should mention passages which Baeza included, from the second version of the play. The translator maintains the tone of the original, although he includes some minor variations, like the following sentence:

\begin{tabular}{|l|l|}
\hline Original & Translation \\
\hline- & "ELISA.- ... Ya verá cómo me manejo. Por \\
& de pronto, voy a anunciar en la Prensa" \\
\hline
\end{tabular}

\section{Floreal Mazía (1952)}

The Argentine Floreal Mazía translated Pygmalion from the English edition published in 1941 for his own country, Argentina, rendering Cockney as lunfardo, a sociolect spoken by the deprived classes of the port area and suburbs of Buenos Aires. The Diccionario del habla de los argentinos defines this linguistic variation as a jargon which was formed and first utilized in Buenos Aires and its slums by immigrants and marginal citizens (see le Bihan 21). Gobello adds two relevant points: lunfardo was influenced by the vocabulary brought into Argentina by immigrants and was used in opposition to general speech (38).

Lunfardo is thus another geolect which shares features with both Cockney and cheli. It is spoken by working-class people who live in the poorest neighbourhoods in the capital. Nevertheless, there is a difference between the English geolect and its Argentine and Spanish counterparts: historical evolution. Cockney developed in a specific area of London during the Low Middle Ages, while cheli and lunfardo are the result of immigration and developed in the suburbs during the nineteenth century.

We can state that Mazía's version is very faithful to the original, despite the changes made by the translator.

1. Mazía maintains the essence of Shaw's text and shows Eliza's insecurity

\subsection{Through tagging:}

\begin{tabular}{|l|l|}
\hline Original & Translation \\
\hline $\begin{array}{l}\text { "THE FLOWER GIRL I'm a good girl, I } \\
\text { am" }\end{array}$ & $\begin{array}{l}\text { "LA FLORISTA.- Sou'na Buena chica, } \\
\text { soy" }\end{array}$ \\
\hline
\end{tabular}

\begin{tabular}{|l|l|}
\hline Original & Translation \\
\hline $\begin{array}{l}\text { "THE FLOWER You ought to be stuffed } \\
\text { with nails, you ought" }\end{array}$ & $\begin{array}{l}\text { "LA FLORISTA.- ¡Tendrían que reyenarlo } \\
\text { de clavos, tendrían!" }\end{array}$ \\
\hline
\end{tabular}

For any Spanish speaker, in the Iberian Peninsula or in the Americas, this structure sounds unnatural, but Mazía maintained it in his translation. I suppose that he decided to do so in 
order to express Eliza's insecurity, instead of using another lexical resource which, as we have seen, does not reproduce exactly the meaning of the original.

\subsection{Sometimes Mazía turns to lexical items, though:}

\begin{tabular}{|l|l|}
\hline Original & Translation \\
\hline "THE FLOWER GIRL I ain't done nothing & "LA FLORISTA.- ¡N'hice nada malo con \\
wrong by speaking to the gentleman. I've a \\
$\begin{array}{l}\text { right to sell flowers if I keep off the kerb. I'm } \\
\text { a respectable girl: so help me" }\end{array}$ & $\begin{array}{l}\text { floreh, si no m'acerco a l'acera. Soy'na } \\
\text { muchacha respetable. Que Dioh m'ampare" }\end{array}$ \\
\hline
\end{tabular}

In this excerpt, the Argentine also changes the words to fit the text to the mentality and speech of Latin America.

\section{Mazía also shows Eliza’s lack of culture}

\subsection{He makes her speak incorrectly by means of:}

Phonetic mistakes: "no le habería 'ruinado la'floreesuna pobre chica", "agueradable", "tartando", "tuayas"

Gramatical errors: "tengo de pagar", "he hacido".

2.2. Despite being uneducated, Eliza constantly shows her good manners by using usted and by the absence of swear words:

\begin{tabular}{|l|l|}
\hline Original & Translation \\
\hline $\begin{array}{l}\text { "LIZA I'm going away. He's off his chump, } \\
\text { he is. I don't want no balmies teaching me" }\end{array}$ & $\begin{array}{l}\text { "LIZA.- Me voy. Ehtá chiflado, ehtá. No } \\
\text { quiero que ningún lunático m'enseñe" }\end{array}$ \\
\hline
\end{tabular}

\section{Juan Leita (1985)}

Leita also based his translation on the English edition of 1941, but he too copied much of Broutá's text. Goñi-Alsúa (2017) has shown that Leita's version is characterized by two concepts: freedom and mistakes. Freedom to take the texts by Shaw and Broutá and copy or rewrite them (we must underline that it was intended for the page, not for the stage) mistakes as, unfortunately, Leita's translation contains very many.

This is the first Spanish edition of Pygmalion to be published after the death of Francisco Franco in 1975. Despite the international economic crisis and Spain's political turmoil, the country underwent a decade of significant advances in all areas of life. With the massive entrance of women into the university, as well as into different areas of specialized work, Spanish society's view of women changed profoundly. Due to this, we could expect to experience a different Eliza, a more modern woman. But Leita depicts her as more vulgar, as we can observe in the following examples.

1. Eliza is insecure, as Leita plays with tags

1.1. He maintains them:

\begin{tabular}{|l|l|}
\hline Original & Translation \\
\hline "LIZA I'm a good girl, I am" & "LISA Yo soy una buena xica. Lo soy" \\
\hline
\end{tabular}


Although he expresses the same message, Leita adapts tagging to the Spanish grammar through the inclusion of a new sentence which bears an equivalent meaning.

1.2. Leita changes some tags to emphasize the sense:

\begin{tabular}{|l|l|}
\hline Original & Translation \\
\hline "LIZA No! I'll call the police, I will" & $\begin{array}{l}\text { "LISA ¡No! Voy a llamar a la policía. Esto } \\
\text { es lo que haré" }\end{array}$ \\
\hline
\end{tabular}

1.3. He develops new tags:

\begin{tabular}{|l|l|}
\hline Original & Translation \\
\hline $\begin{array}{l}\text { "LIZA. I got my feelings same as anyone } \\
\text { else" }\end{array}$ & $\begin{array}{l}\text { "LISA Mis sentimientos son los mismos } \\
\text { que los de cualquiera, esto es lo que son" }\end{array}$ \\
\hline
\end{tabular}

1.4. He eliminates tags:

\begin{tabular}{|l|l|}
\hline Original & Translation \\
\hline $\begin{array}{l}\text { "THE FLOWER GIRL Ain't no call to } \\
\text { meddle with me, he ain't" }\end{array}$ & $\begin{array}{l}\text { "LA JOVEN FLORISTA Esto no es ningún } \\
\text { motivo para meterse conmigo" }\end{array}$ \\
\hline
\end{tabular}

As we can see, the changes which Leita includes do not follow a regular a pattern.

2. Eliza is more vulgar

\subsection{Lexical choices:}

\begin{tabular}{|l|l|}
\hline Original & Translation \\
\hline $\begin{array}{l}\text { "THE FLOWER GIRL Ah--ah--ah--ow--ow- } \\
\text {-ow--oo! I won't be called a baggage when } \\
\text { I've offered to pay like any lady" }\end{array}$ & $\begin{array}{l}\text { audi! ¿Tienen que llamarme ramera } \\
\text { cuando me he ofrecido a pagar igual que } \\
\text { una señora?" }\end{array}$ \\
\hline
\end{tabular}

There is no doubt that "ramera" is more emphatic than "baggage".

2.2. Grammatical mistakes linked to mispronunciation:

\begin{tabular}{|l|l|}
\hline Original & Translation \\
\hline $\begin{array}{l}\text { "THE FLOWER GIRL I can give you } \\
\text { change for a tanner, kind lady" }\end{array}$ & $\begin{array}{l}\text { "LA JOVEN FLORISTA La pueo dar } \\
\text { cambio si quiere, distinguía señora" }\end{array}$ \\
\hline
\end{tabular}

This is a clear example of "laismo", a typical grammatical mistake committed in the area of Madrid and Valladolid, related to the use of the object pronouns.

3. Eliza is more insolent

\begin{tabular}{|l|l|}
\hline Original & Translation \\
\hline "ELIZA Now you know, don’t you?" & "ELIZA ¿Se entera usté ahora?" \\
\hline
\end{tabular}


Although "enterarse" could convey the same meaning as "saber", in colloquial Spanish the former sounds more emphatic and ruder. Additionally, in this context, the inclusion of "usté", far from being a demonstration of good manners, tends to the opposite.

\section{Julio Broutá (1990)}

Apparently, this edition is a reprint of the original which Brouta gave to the publisher in 1919, as in the first pages we read that Julio Broutá was the translator. But as we delve into the text, we see that several changes and amendments have been made by an unknown person. I imagine that it was the editor, whose name is unknown.

What is remarkable about this version is the fact that it is obviously based on the text written by Shaw in 1913, but the editor has introduced a scene taken from the 1941 version published. This inclusion is not inconsequential because it clearly reinforces the desire for being independence which characterizes Eliza throughout the play. Again, it is important to remember that we are in 1990 and the position of women in Spain has progressed to a great extent. We thus have a new Eliza in accord with the new times.

\section{Eliza's greater security}

1.1. The choice of words and their position in the sentence:

\begin{tabular}{|l|l|}
\hline Original & Translation \\
\hline $\begin{array}{l}\text { "... I can be civil ... which is more than you } \\
\text { can" }\end{array}$ & “... Se tratar a la gente y usted, no" \\
\hline
\end{tabular}

Not only is the choice of words - "se tratar a la gente" - important but also the additions and placement of the negative adverb which, at the end of the sentence, sustains the negative aspect.

1.2. Moreover, the editor adds the following:

\begin{tabular}{|l|l|}
\hline Original & Translation \\
\hline- & $\begin{array}{l}\text { "Estoy segura de que con poco trabajo me } \\
\text { crearé una posición independiente y } \\
\text { brillante" }\end{array}$ \\
\hline
\end{tabular}

Although Shaw included this very same concept in the second edition of Pygmalion (1941), his message is more clearly emphasized in the Spanish version, thanks to this addition.

2 Although Eliza's vocabulary is the same as in Broutá, the editor selects more standard lexical items and corrects most of the phonetics, which undoes the cheli characterization. Eliza sounds more cultured and less sociolectal.

\begin{tabular}{|l|l|}
\hline Broutá & Editor \\
\hline "da leciones de prenunciación" & "da lecciones de pronunciación" \\
\hline
\end{tabular}

\begin{tabular}{|l|l|}
\hline Broutá & Editor \\
\hline ¿qué s'ha figurao usté?” & “qué se ha figurado usted?” \\
\hline
\end{tabular}

\begin{tabular}{|l|l}
\hline Broutá & Editor
\end{tabular}


The time which elapsed between the first translation and this one shows the remarkable change in Spanish society, as now Eliza is able to express confidence and hope for her future. To this extent, we could claim that Bernard Shaw was ahead of his time, not only a feminist, but a man who foresaw the evolution women's position would undergo.

\section{Miguel Cisneros (2016)}

Cisneros published his translation in 2016. In the prologue, he explains that he used the version of Pygmalion which Shaw authorized and published in 1941.

Cisneros provides a critical, historical, and textual study with copious footnotes. He explains that he has neutralized the dialect in the play, because it is not possible to translate linguistic variations, and asserts that it is the stage director and the actors who must decide how to reflect them on stage. On this point, it is worth quoting Perteghella's comment that:

There are several strategies for translating dialect and slang for the stage, and these strategies, together with choices in production, will manipulate the target reception of the play. Some translators prefer to substitute dialect with standard language, although the nuances and musicality, as well as some aspects of characterization will inevitably be lost. (46)

We should also add that this translation is characterized by its faithfulness to the original, even though, in neutralizing the dialect, Eliza certainly changes. On the other hand, the translator has succeeded in reflecting the language spoken in contemporary Spain, so the reader feels that this text is very close to them and their reality.

Regarding Eliza's personality, we could claim that:

1. Eliza shows her insecurity due to the fact that Cisneros maintains the tagging, making it grammatically correct in Spanish

\begin{tabular}{|l|l|}
\hline Original & Translation \\
\hline $\begin{array}{l}\text { "THE FLOWER GIRL I'm a good girl, I } \\
\text { am" }\end{array}$ & $\begin{array}{l}\text { "LA VENDEDORA DE FLORES. Yo soy } \\
\text { buena soy una chica buena" }\end{array}$ \\
\hline
\end{tabular}

2. Nonetheless, Cisneros shows us "another" Eliza

2.1. She appears to be more nervous, as seen in the repetition of the personal pronoun "me":

\begin{tabular}{|l|l|}
\hline Original & Translation \\
\hline $\begin{array}{l}\text { "They'll take away my character and drive } \\
\text { me on the streets for speaking to gentlemen. } \\
\text { They_-" }\end{array}$ & $\begin{array}{l}\text { "Me arruinarán la fama y me obligarán a } \\
\text { arrastrarme por la calle por hablar con } \\
\text { caballeros. Me, me ..." }\end{array}$ \\
\hline
\end{tabular}

2.2. She defends herself, as is shown by the change of the subjects from the third to the first person:

\begin{tabular}{|l|l|}
\hline Original & Translation \\
\hline $\begin{array}{l}\text { "THE FLOWER GIRL. Poor girl! Hard } \\
\text { enough for her to live without being worrited } \\
\text { and chivied" }\end{array}$ & $\begin{array}{l}\text { "LA VENDEDORA DE FLORES. Probe } \\
\text { chica. Con lo dura que es mi vida como } \\
\text { para que encima vengan a insultarme y } \\
\text { darme la lata" }\end{array}$ \\
\hline
\end{tabular}


2.3. This Eliza is also more coarse, due to Cisneros' choice of words, as he does not use phonetics and, as we have mentioned before, he eliminates the dialectal markers in his version:

\begin{tabular}{|l|l|}
\hline Original & Translation \\
\hline $\begin{array}{l}\text { "THE FLOWER GIRL. Nah then, Freddy: } \\
\text { look wh' y' gowin, deah" }\end{array}$ & $\begin{array}{l}\text { "LA VENDEDORA DE FLORES. ¡Oye, } \\
\text { Freddy, mira dónde pisas, coño!” }\end{array}$ \\
\hline
\end{tabular}

\begin{tabular}{|l|l|}
\hline Original & Translation \\
\hline $\begin{array}{l}\text { "THE FLOWER GIRL There's menners f' } \\
\text { yer! Te-oobanches o voylets trod into the } \\
\text { mad" }\end{array}$ & $\begin{array}{l}\text { "LA VENDEDORA DE FLORES. iQué } \\
\text { modales! Dos ramos de violetas al carajo" }\end{array}$ \\
\hline
\end{tabular}

\begin{tabular}{|l|l|}
\hline Original & Translation \\
\hline $\begin{array}{l}\text { "THE FLOWER GIRL Oh, what harm is } \\
\text { there in my leaving Lisson Grove?" }\end{array}$ & "LA VENDEDORA DE FLORES. ¿Y qué \\
hay de malo en largarse de Lisson Grove?" \\
\hline
\end{tabular}

\section{Concluding Remarks}

In a society in which status is signalled by language use, its inclusion in a literary work marks a difference and has a deep significance. As a consequence, the distinction between linguistic variations should appear in translations. Nevertheless, this issue is problematic in both theory and practice since, as we have observed, translators' choices may bring changes in the portrayal of the characters.

Considering all these extracts from Pygmalion, we can conclude that there are a variety of "Elizas", as the translators have all modified certain features of her personality. Previously, I described Eliza as well-mannered, resolute, strong-willed, independent, witty, a young woman with dignity and self-respect who is determined to improve in life although she lacks education, but these aspects have been emphasized, softened, or even eliminated while others have been added.

In chronological order, in Broutá's translation, Eliza's insecurity is diluted, she defends herself more strongly, and in those moments she is shown to be ruder than in the original; however, when she is selling flowers, she behaves more politely than in the original. Regarding the dialect, she sounds colloquial rather than dialectal, as cheli is not as deeply marked as Cockney. Baeza, on the other hand, shows a more confident Eliza who also defends herself and her honour more vehemently; she is ruder, becoming vulgar in some instances. Mazía maintains her insecurity, but transforms her into a person with better manners. As we have mentioned, the Argentine rendered Cockney with lunfardo and, as a result of this choice, his Eliza is perceived as uneducated. Leita is the translator who shows Eliza in the most negative light, since he emphasizes her insecurity, rudeness, and lack of culture. In the 1990 edition, in which an unknown editor introduced changes to Broutá's translation, we perceive a more confident Eliza, more cultured and less colloquial. One could deduce that this change was a conscious decision made by the editor to modernize the character and to adapt her to the values of contemporary society. Lastly, in the new century, Cisneros shows Eliza's original lack of confidence, but he presents a coarser, nervous person who does not speak any specific dialect.

To conclude, we should focus on the fact that scholars have mostly paid attention to the translation of dialects in literary works: whether it is possible or not, whether it is 
advisable or not, or how they should be rendered, especially in plays, where everything happens on stage, before the eyes of the audience. Nevertheless, we should also acknowledge that it is important to translate linguistic variation to maintain the real self of characters, because through every nuance, the author transmits an idea which helps us to understand the literary work to its full extent.

\section{Works Cited}

Arniches, Carlos. El amigo Melquiades. Madrid: Austral, 1993.

Esslin, Martin. The Field of Drama. London: Methuen, 1990.

Fernández Insuela, Antonio. "Sobre la recepción de Brecht en revistas culturales españolas de postguerra”. Anuario de Estudios Filológicos XVI (1993): 123-138.

Furlanetto, Priscila Fernanda. Análise descritiva da tradução para o português de Pygmalion de George Bernard Shaw por Millôr Fernandes. Master's dissertation. Universidade Estadual Paulista, 2008. http://repositorio.unesp.br/handle/11449/94101.

Gallardo, Bárbara Cristina. “Why can't women talk like a man? ”: An Investigation of Gender in the Play Pygmalion by Bernard Shaw. Master's dissertation. Universidad de Florianópolis, 2001.

Gimeno Menéndez, Francisco. Dialectología y sociolingüística españolas. Alicante: Universidad de Alicante, 1990.

Gobello, José. Nuevo diccionario lunfardo. Buenos Aires: Corregidor, 1990.

Goñi-Alsúa, Edurne. Traducción y censura, traducción de dialectos: Las versiones al castellano de Pigmalión de George Bernard Shaw. Doctoral thesis. Universidad del País Vasco, 2017.

Hatim, Basil and Mason, Ian. The Translator as Communicator. Oxford: Routledge, 1997.

Holmes, James S., ed. Translated! Papers on Literary Translation and Translation Studies. Amsterdam: Rodopi, 1988.

Le Bihan, Ulysse. Italianismos en el habla de la Argentina: herencia de la inmigración italiana. Cocoliche y lunfardo. Master's dissertation. Universitetet i Oslo, 2011. https://www.duo.uio.no/bitstream/handle/10852/25849/MASTEROPPGAVExIxSPAN SKxHFxVxRx2011.pdf?sequence $=1$.

Matlaw, Myron. "The Denouement of Pygmalion". Modern Drama 1 (1958): 29-34.

Matthews, William. Cockney Past and Present: A Short History of the Dialect of London. London: Routledge, 1972.

Merino Álvarez, Raquel. Traducción, tradición y manipulación: Teatro inglés en España 1950-1990. León: Universidad de León y UPV/EHU, 1994.

- "A Framework for the Description of Drama Translations". Revista Canaria de Estudios Ingleses 29 (1994): 127-138.

Miguel González, Marta. "El cine de Hollywood y la censura franquista de la España de los años 40: un cine bajo palio". Traducción y censura, inglés-español 1939-1985: estudio preliminar. Ed. Rosa Rabadán. León: Universidad de León, 2000. 61-86.

Muñoz Cáliz, Berta. "El teatro silenciado por la censura franquista". PerAbbat. Boletín Filológico de Actualización Académica y Didáctica 3 (2007): 85-96.

Pacheco, Sebastián Altamirano. "Pygmalion: la fuerza creadora ajena al amor". Revista de Lenguas Modernas 18 (2013): 45-52.

Perteghella, Manuela. "Language and Politics on Stage: Strategies for Translating Dialect and Slang with References to Shaw's Pygmalion and Bond's Saved'. Translation Review 64 (2002): 45-53.

Seco, Manuel. Arniches y el habla de Madrid. Madrid: Alfaguara, 1970.

Shaw, George Bernard. Pigmalión. Trans. Ricardo Baeza. Buenos Aires: Hachette, 1944. 
Teatro Completo II. Trans. Floreal Mazía. Buenos Aires: Editorial Sudamericana, .Comedias escogidas. Trans. Julio Broutá. Prologue A.C. Ward. 7th ed, Madrid: Aguilar, 1968.

Pigmalión. Trans. Juan Leita. Barcelona: Seix Barral, 1985.

- Pigmalión. Trans. Julio Broutá. Barcelona: Plaza y Janés, 1990.

_. Pigmalión. Trans. Miguel Cisneros Perales. Madrid: Cátedra. Letras Universales, 2016.

-. Pygmalion. London: Penguin Books, 1990.

Shaw, George Bernard and Alan Jay Lerner. Pygmalion. A Romance in Five Acts and My Fair Lady. New York: Signet Classics, 1980.

Soto Vázquez, Adolfo Luis. "El arte de traducir la expresión dialectal". Insights into Translation. Ed. Adolfo Luis Soto Vázquez. A Coruña: Universidade de A Coruña, 1998. 23-31.

Tello Fons, Isabel. La traducción del dialecto: análisis descriptivo del dialecto geográfico y social en un corpus de novelas en lengua inglesa y su traducción al español. $\mathrm{PhD}$ thesis. Universitat Jaume I, 2011.

Received: 19 September 2017

Revised version accepted: 5 December 2017

Edurne Goñi Alsúa, doctor in English Philology and graduate in Hispanic Philology, teaches in the Public University of Navarre (UPNA) and in the International University of La Rioja (UNIR). The focus of her doctoral thesis was the reception of the works of Bernard Shaw in the Hispanic countries, the translation of dialects and the translation of the Cockney dialect in the six versions of Pigmalion in Spanish. She is currently working in the publishing of this work and preparing an article on the reception of the works of Oscar Wilde.

mirenedurne.goni@unavarra.es 